() Нікіфорова О.С., Саник О.В., Дельва М.Ю.

УДК 616.857-08

DOI https://doi.org/10.31718/mep.2021.25.5-6.07

\title{
КЛІНІЧНИЙ ВИПАДОК МОЖЛИВОЇ МІГРЕНІ З АУРОЮ, УСКЛАДНЕНОЇ МІГРЕНОЗНИМ ІНФАРКТОМ
}

\author{
Нікіфорова О.С., Саник О.В., Дельва М.Ю.
}

Полтавський державний медичний університет, м. Полтава

Дана робота є фррагментом НДР кафедри нервових хвороб з нейрохірургією та медичною генетикою Української медичної стоматологічної академії: «Оптимізація діагностики, прогнозування та профрілактики нейропсихологічних розладів при органічних захворюваннях нервової системи», № державної реєстрації: $0120 U 104165$.

We present a clinical case of ischemic stroke in a man with a new-onset migraine attack. Clinical case. A 25-year-old man was admitted to the acute cerebrovascular department due to severe throbbing headache in the left temporal area, vomiting, impaired vision on the right and numbness of the right leg. Complaints appeared abruptly in the form of scotoma in the right visual field. 20 minutes later, severe throbbing headache, nausea and numbness of the right leg developed. The event was preceded by sleep deprivation for 2 days. The patient's mother has migraine with aura. Previously, the patient never had such attacks. On examination: right-sided homonymous upper-quadrant hemianopsia, hypoesthesia of the right leg. Brain MRI - focal hyperintensity at T2 and DWI in the left occipital region (acute ischemic stroke). The patient took aspirin at a dose of $300 \mathrm{mg}$ for the first day, then $100 \mathrm{mg}$ per day and valproic acid at a dose of $1200 \mathrm{mg}$ per day. Two days after hospitalization, the patient experienced recovery of sensitivity in the right leg and regression of right-sided homonymous upper quadrant hemianopsia to small scotoma. The patient was discharged on the 5th day with a small right scotoma. It is recommended to continue taking aspirin $100 \mathrm{mg} /$ day and valproic acid 1200 $\mathrm{mg} /$ day for the secondary prevention of migraine attacks and stroke. Discussion. The peculiarities of this case include the lack of history of migraine (at least 5 or more migrainous headache attacks) and the development of severe migraine attack with prolonged aura symptoms, which was triggered by sleep deprivation and eventually evolved into ischemic stroke. Conclusions. It is necessary to consider the possibility of ischemic stroke even in the cases of a new-onset migraine attack. If migrainous aura duration exceeds 60 minutes, it is necessary to perform a brain MRI to detect the early signs of cerebral ischemia.

Key words: probable migraine, migrainous infarction, diagnosis, treatment.

Ми наводимо клінічне спостереження ішемічного інсульту у чоловіка з мігренозним нападом з аурою, що вперше виник. Клінічне спостереження. 25-річний чоловік доставлений у відділення гострої церебральної патології з вираженим головним болем в лівій скроневій ділянці, що супроводжувався блюванням, порушенням зору справа та відчуттям оніміння в правій нозі. Захворів гостро з появи часткової скотоми в полі зору справа, через 20 хв. з'явилися виражений головний біль пульсуючого характеру, нудота, оніміння в правій нозі. Розвитку нападу передувала депривація сну протягом 2 днів. Має обтяжену за мігренню з аурою спадковість. Раніше подібних нападів не спостерігалось. При огляді: правобічна гомонімна верхньо-квадрантна геміанопсія, гіпестезія правої гомілки. MPT головного мозку - гіперінтенсивне на T2 та DWI вогнище в лівій потиличній ділянці (гостра стадія ішемічного інсульту). Пацієнт отримував аспірин в дозі 300 мг за першу добу, потім 100 мг на добу і вальпроєву кислоту в дозі 1200 мг на добу. Через 2 дні після госпіталізації пацієнт відчув покращення у вигляді відновлення чутливості в правій нозі та регресу правобічної гомонімної верхньої квадрантної геміанопсії до невеликої скотоми. Виписаний із стаціонару на 5-ту добу, зберігалась правобічна скотома. Рекомендовано продовжити прийом аспірину 100 мг/добу та вальпроєвої кислоти 1200 мг/добу з метою вторинної профілактики мігренозних нападів та інсульту. Обговорення. Особливістю даного випадку є відсутність мігрені (5 і більше повторних мігренозних нападів) в анамнезі, тяжкий мігренозний напад, спровокований депривацією сну, а також тривалі симптоми аури, які еволюціонували у симптоми ішемічного інсульту. Висновки. Необхідно враховувати можливість розвитку ішемічного інсульту навіть при мігренозному нападі, що вперше виник. В клінічних випадках, коли тривалість аури перевищує 60 хвилин необхідно провести МРТ головного мозку для виявлення ранніх ознак церебральної ішемії.

Ключові слова: можлива мігрень, мігренозний інфраркт, діагностика, лікування.

\section{Вступ}

Зазвичай мігрень вважається відносно доброякісним неврологічним розладом 3 повністю оборотними вогнищевими та загальномозковими симптомами. Однак, існують тісні асоціації між мігренню з аурою та ішемічним інсультом [1-3]. Згідно Міжнародної класифрікації головного болю 3-го перегляду мігренозний інфаркт (MI) визначається як один або декілька симптомів мігренозної аури, що зберігаються більше 60 хвилин у поєднанні з ішемічним ураженням мозку у відповідній ділянці, що виявляється за допомогою нейровізуалізації, під час типової атаки мігрені з аурою [4].

До теперішнього часу більшість неврологів не обізнана в потрібному обсязі з принципами діагностики та лікування Ml, що перед усім пов'язано з недостатнім використанням міжнародних стандартів діагностики мігрені та інших типів первинного головного болю [5].

Рівень захворюваності на Ml низький, близько 0,8

*Цитування при атестації кадрів: Нікіфорова О.С., Саник О.В., Дельва М.Ю. Клінічний випадок можливої мігрені з аурою, ускладненої мігренозним інфрарктом// Проблеми екології і медицини. - 2021. - Т. 25, № 5-6. - С. 28-31. 
на 100000 людино-років [6], що менше ніж 1\% від усіх ішемічних інсультів [7]. Однак, у молодшого населення Ml становить значно більшу частку - до $20 \%$ від всіх ішемічних інсультів [8]. MI вражає жінок у два-три рази частіше, ніж чоловіків [9]. Це пояснюється вищою поширеністю мігрені серед жінок (18\% проти 6-7\%), особливо коли мігрень поєднується з курінням та пероральним прийомом контрацептивів $[3,10]$.

$\mathrm{Ha}$ сьогоднішній день патогенез мігреньасоційованого інсульту та терапевтичні підходи поки що залишаються не до кінця з'ясованими. Ми наводимо власне клінічне спостереження ішемічного інсульту у пацієнта з тяжким мігренозним нападом з аурою, що вперше виник (згідно Міжнародної класифікації головного болю 3-го перегляду - 3 «Можливою мігренню з аурою» [4]).

\section{Клінічне спостереження}

25-річний чоловік доставлений у відділення гострої церебральної патології з вираженим головним болем в лівій скроневій ділянці, що супроводжувався блюванням, порушенням зору справа та відчуттям оніміння в правій нозі. Даний напад почався гостро із зату-

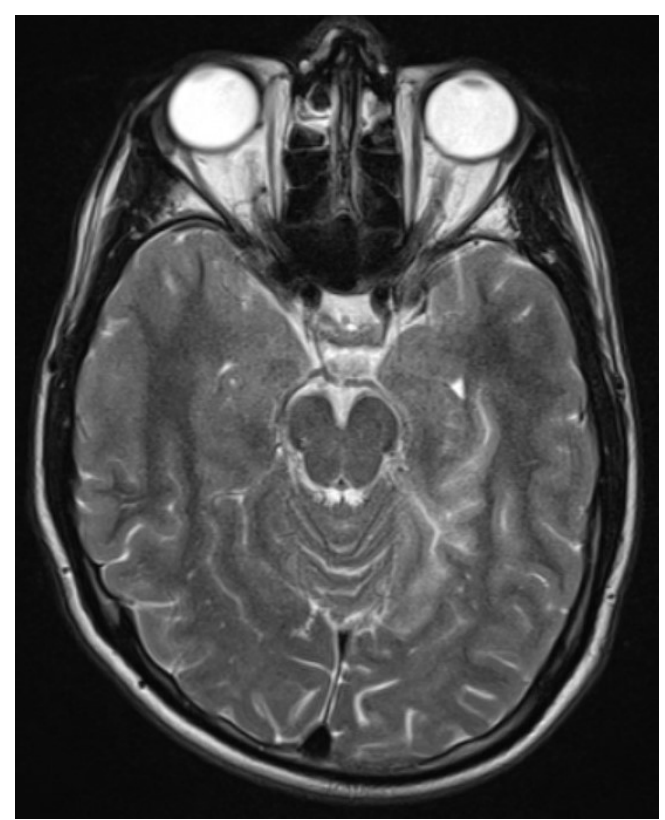

манення зору та появи часткової скотоми справа, до яких через 20 хв. приєднався виражений головний біль пульсуючого характеру та нудота. Далі з'явилося оніміння в правій нозі. Пацієнт прийняв золмітриптан 2,5 мг перорально - без будь-якого ефекту, через дві години після першої дози повторно прийняв таку ж дозу препарату. Розвитку нападу передувала депривація сну протягом 2 днів (нічні зміни). Має обтяжену за мігренню спадковість (у матері - мігрень 3 аурою). Раніше подібних нападів не спостерігалось. В анамнезі відсутні будь-які соматичні та неврологічні захворювання.

Під час огляду виявлені вогнищеві симптоми у вигляді правобічної гомонімної верхньо-квадрантної геміанопсії, гіпестезії правої гомілки, що оцінено у 2 бали за Шкалою інсульта Національного інституту здоров'я (NIHSS). За даними магнітної резонансної томографії (МРТ) головного мозку виявлено гіперінтенсивне на T2, T2 TIRM та DWI вогнище $6,2 \times 3,0 \times 2,3 \mathrm{~cm}$ в лівій потиличній ділянці (басейн кровопостачання лівої задньої мозкової артерії), що відповідає гострій стадії ішемічного інсульту (рис.1).

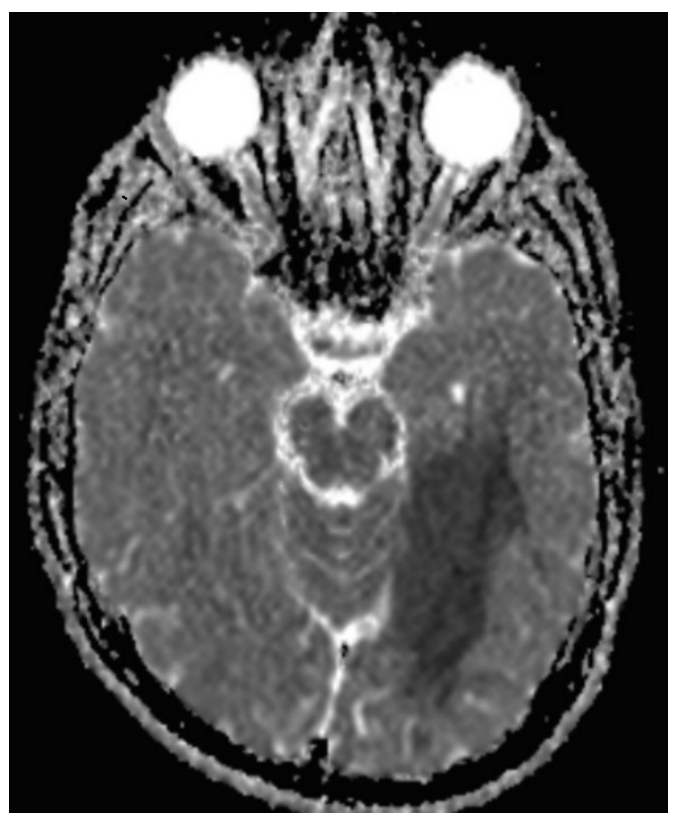

Pис.1. МРТ: в режимі T2 - гіперінтенсивне вогнище в лівій потиличній ділянці (басейн кровопостачання лівої задньої мозкової артерії);

в режимі ADC - гіпоінтесивне вогнище в тій самій ділянці.

Комп'ютерна томографрічна ангіографрія не виявила змін та ознак тромбозу/диссекції судин. Ехокардіографрія не виявила відкритого овального отвору. Електрокардіографія та моніторинг артеріального тиску не виявили патологічних змін. Електроенцефалографія епілептиформна активність в лівій скроневій ділянці. В аналізі крові - нормальні показники кількості тромбоцитів, ШОЕ, С-реактивного білка, антитромбіну III. Антинуклеарних антитіл, ревматоїдного фактору та антикардіоліпінових антитіл в крові не виявлено.

Враховуючи час від початку симптомів та відсутність показань щодо системної тромболітичної терапії (2 бали за NIHSS), пацієнту розпочата терапія аспірином в дозі 300 мг за першу добу, потім 100 мг на добу і вальпроєвою кислотою в дозі 1200 мг на добу. Через 2 дні після госпіталізації пацієнт відчув покращення у вигляді відновлення чутливості в правій нозі та регресу правобічної гомонімної верхньої квадрантної геміа- нопсії до невеликої скотоми. Виписаний із стаціонару на 5-ту добу, зберігалась правобічна скотома. Рекомендовано продовжити прийом аспірину 100 мг/добу та вальпроєвої кислоти 1200 мг/добу з метою вторинної профрілактики мігренозних нападів та інсульту.

\section{Результати та їх обговорення}

Ми описали пацієнта у якого розвився ішемічний інсульт після першої тяжкої мігренозної атаки. Особливістю даного випадку є відсутність мігрені (5 і більше повторних мігренозних нападів) в анамнезі; тяжкий мігренозний напад, який був спровокований депривацією сну і тривалі симптоми аури, які на фоні застосування триптану еволюціонували у симптоми ішемічного інсульту.

Механізми підвищеного ризику ішемічного інсульту у молодих пацієнтів з мігренню з аурою залишаються до кінця невідомими. Їх не пов'язують зі збільшенням 
звичайних фракторів ризику інсульту, таких як діабет, артеріальна гіпертензія та підвищений рівень холестерину [11]. Найбільшими факторами ризику у молодих пацієнтів з мігренню вважаються жіноча стать в поєднанні з курінням та пероральним прийомом контрацептивів [3, 10].

Одна $з$ найбільш досліджуваних патофрізіологічних теорій MI включає феномен поширення кортикальної депресії (ПКД) [12]. ПКД характеризується як хвиля деполяризації нейронів, яка поширюється з потиличної зони мозку вперед по корі [13] з подальшим зменшенням мозкового кровотоку, що відповідає клінічним симптомам аури, і в рідкісних випадках може досягати ішемічного рівня і призводити до інфаркту мозку [14].

Інші теорії MI пов'язані з ендотеліальною дисфункцією та гіперкоагуляцією під час аури [15]. Також, мігрень може бути асоційована з певними патологічними станами (наприклад, відкрите овальне вікно [16] і диссекція хребтової артерії [17]). Той фракт, що певні генетичні синдроми (наприклад, церебральна аутосомно-домінантна артеріопатія з підкірковими інфарктами та лейкоенцефалопатією - CADASIL) асоціюються 3 мігренню та інсультами, може свідчити про генетичні механізми, i, ймовірно, вроджені зміни стінки дрібних мозкових судин [18].

Іншою потенційною причиною $\mathrm{Ml} €$ несприятливий вплив лікарських засобів для абортивної терапії мігрені [17]. Триптани не показали подовження фази аури в клінічних випробуваннях [19], але були пов'язані з інсультом у поодиноких випадках $[20,21]$.

Ще одне рідкісне явище - мігралепсія. Поєднання епілепсії з мігренню, адже мігрень та епілепсія мають кілька спільних патогенних механізмів. КДП викликає дисбаланс між збудливими і гальмівними механізмами в передачі нервових імпульсів через глутамат і патологічну активацію іонних каналів, і $є$ спільною патофрізіологічною ланкою, що задіяна як при мігрені, так i при епілепсії [22]. Не дивно, що протиепілептичні препарати ефективні при мігрені.

Зв'язок між мігренню та церебральною ішемією підтверджують результати популяційних досліджень на основі оцінки МРТ. У осіб, які страждають на мігрень із аурою, більша кількість уражень білої речовини мозку та ішемічних інфрарктів, ніж в контрольній групі. Причому, ці ураження спостерігались переважно в басейні задньої мозкової артерії і траплялись в 12 разів частіше, ніж у контрольній групі [23].

Інсульт у молодому віці означає інвалідність та втрату працездатності набагато раніше в житті і може нести більший тягар, ніж у літніх людей. Тож визначення фракторів ризику розвитку MI а також чітких рекомендацій щодо менеджменту MI $€$ важливою медичною та соціально-економічною проблемою. На даний час немає чітких рекомендацій щодо фрармакотерапії для первинної та вторинної профілактики ішемічного інсульту у пацієнтів з мігренню.

Базуючись на вище наведеному спостереженні, описаних в літературі інших клінічних випадках та можливому патогенезі захворювання, слід звернути увагу на наступні моменти.

У пацієнтів молодого віку можливою причиною ішемічного інсульту може бути мігренозний напад 3 аурою, що вперше виник і це потребує специфічного менеджменту такого пацієнта.

Важливо визначити та модифікувати судинні фрактори ризику у пацієнтів з мігренню $з$ аурою, включаю- чи високий артеріальний тиск, куріння, використання оральних контрацептивів та зміну способу життя.

Деякі дослідження показали, що абортивна терапія нападів мігрені триптанами $є$ більш безпечною та ефективною при їх прийомі після завершення фази аури, при появі легкого головного болю [24-26].

Для первинної профрілактики MI доцільним є використання ліків, що здатні впливати як на мігренозні напади, так і на судинні фрактори ризику ішемічного інсульту (наприклад, у пацієнта з мігренню та гіпертонічною хворобою доцільно призначити кандесартан [27], у пацієнта 3 мігренню та ожирінням - топірамат [28]).

\section{Перспективи подальших досліджень}

В подальшому необхідно дослідити питому частку мігренозних інфарктів в структурі ішемічних інсультів серед мешканців міста Полтава.

\section{Висновки}

Необхідно враховувати можливість розвитку ішемічного інсульту навіть при мігренозному нападі 3 аурою, що вперше виник.

В клінічних випадках, коли тривалість мігренозної аури перевищує 60 хвилин, необхідно провести МРТ головного мозку для виявлення ранніх ознак церебральної ішемії, а також уникати призначення судиннозвужуючих препаратів (триптани, ерготаміни, кофеїн).

\section{Література}

1. Bigal ME, Kurth T, Santanello N, Buse D, Golden W, Robbins $M$, et al. Migraine and cardiovascular disease: a population-based study. Neurology. 2010 Feb;74(8):62835.

2. Hu X, Zhou $Y$, Zhao H, Peng $C$. Migraine and the risk of stroke: an updated meta-analysis of prospective cohort studies. Neurol Sci Off J Ital Neurol Soc Ital Soc Clin Neurophysiol. 2017 Jan;38(1):33-40.

3. Spector JT, Kahn SR, Jones MR, Jayakumar M, Dalal D, Nazarian S. Migraine headache and ischemic stroke risk: an updated meta-analysis. Am J Med. 2010 Jul;123(7):612-24.

4. Headache Classification Committee of the International Headache Society (IHS) The International Classification of Headache Disorders, 3rd edition. Cephalalgia. 2018 Jan;38(1):1-211.

5. Delva M, Delva I. (2021). Analysis of primary headaches management in poltava regions. Wiad Lek. 2021 Jan;74(1):118-121.

6. Plato BM. Rare Complications of Migraine With Aura. Headache. 2016 Sep;56(8):1373-9.

7. Zhang Y, Parikh A, Qian S. Migraine and stroke. Stroke Vasc Neurol. 2017 Sep;2(3):160-7.

8. Bogousslavsky J, Pierre P. Ischemic stroke in patients under age 45. Neurol Clin. 1992 Feb;10(1):113-24.

9. Laurell K, Artto V, Bendtsen L, Hagen K, Kallela M, Meyer EL, et al. Migrainous infarction: a Nordic multicenter study. Eur J Neurol. 2011 Oct;18(10):1220-6.

10. Schürks M, Rist PM, Bigal ME, Buring JE, Lipton RB, Kurth T. Migraine and cardiovascular disease: systematic review and meta-analysis. BMJ. 2009 Oct;339:b3914.

11. MacClellan LR, Giles W, Cole J, Wozniak M, Stern B, Mitchell BD, et al. Probable migraine with visual aura and risk of ischemic stroke: the stroke prevention in young women study. Stroke. 2007 Sep;38(9):2438-45.

12. Dreier JP, Reiffurth C, Woitzik J, Hartings JA, Drenckhahn $\mathrm{C}$, Windler $\mathrm{C}$, et al. How spreading depolarization can be the pathophysiological correlate of both migraine aura and stroke. Acta Neurochir Suppl. 2015;120:137-40.

13. Lauritzen M, Dreier JP, Fabricius M, Hartings JA, Graf R, Strong AJ. Clinical relevance of cortical spreading depression in neurological disorders: migraine, malignant stroke, subarachnoid and intracranial hemorrhage, and traumatic 
brain injury. J Cereb blood flow Metab Off $\mathrm{J}$ Int Soc Cereb Blood Flow Metab. 2011 Jan;31(1):17-35.

14. Nozari A, Dilekoz E, Sukhotinsky I, Stein T, EikermannHaerter K, Liu C, et al. Microemboli may link spreading depression, migraine aura, and patent foramen ovale. Ann Neurol. 2010 Feb;67(2):221-9.

15. Ducros A. [Genetics of migraine]. Rev Neurol (Paris). 2013 May; 169(5):360-71.

16. Liu K, Wang BZ, Hao Y, Song S, Pan M. The Correlation Between Migraine and Patent Foramen Ovale. Front Neurol. 2020;11:543485

17. Pezzini A, Del Zotto E, Giossi A, Volonghi I, Grassi M, Padovani A. The migraine-ischemic stroke connection: potential pathogenic mechanisms. Curr Mol Med. 2009 Mar;9(2):215-26.

18. Tan RYY, Markus HS. CADASIL: Migraine, Encephalopathy, Stroke and Their Inter-Relationships. PLoS One. 2016;11(6):e0157613.

19. Bates D, Ashford E, Dawson R, Ensink FB, Gilhus NE, Olesen J, et al. Subcutaneous sumatriptan during the migraine aura. Sumatriptan Aura Study Group. Neurology. 1994 Sep;44(9):1587-92.

20. Jayamaha JE, Street MK. Fatal cerebellar infarction in a migraine sufferer whilst receiving sumatriptan. Intensive Care Med. 1995 Jan;21(1):82-3.

21. Vijayan $\mathrm{N}$, Peacock JH. Spinal cord infarction during use of zolmitriptan: a case report. Headache. 2000 Jan;40(1):57-60.
22. Calabresi P, Galletti F, Rossi C, Sarchielli P, Cupini LM Antiepileptic drugs in migraine: from clinical aspects to cellular mechanisms. Trends Pharmacol Sci. 2007 Apr;28(4):188-95.

23. Kruit MC, Launer LJ, Ferrari MD, van Buchem MA. Infarcts in the posterior circulation territory in migraine. The population-based MRI CAMERA study. Brain. 2005

24. Hansen JM, Goadsby PJ, Charles A. Reduced efficacy of sumatriptan in migraine with aura vs without aura. Neurology. 2015 May;84(18):1880-5.

25. Hansen JM, Charles A. Differences in treatment response between migraine with aura and migraine without aura: lessons from clinical practice and RCTs. J Headache Pain [Internet]. 2019:20(1):96. Available from: https://doi.org/10.1186/s10194-019-1046-4

26. Schoenen J. When should triptans be taken during a migraine attack? CNS Drugs. 2001;15(8):583-7.

27. Owada K. Efficacy of candesartan in the treatment of migraine in hypertensive patients. Hypertens Res. 2004 Jun;27(6):441-6.

28. Krymchantowski A, Tavares $\mathrm{C}$. Weight variations in patients receiving topiramate migraine prophylaxis in a tertiary care setting. MedGenMed. 2004 Jul;6(3):48.

Матеріал надійшов до редакції 10.11.2021. 